\title{
Solar retinopathy: the yellow dot and the rising sun
}

\author{
Abhishek Sheemar, Brijesh Takkar, Shreyas Temkar, Pradeep Venkatesh
}

Dr Rajendra Prasad Centre for Ophthalmic Sciences, All India Institute of Medical Sciences, New Delhi, India

\section{Correspondence to Dr Brijesh Takkar, britak.aiims@gmail.com}

Accepted 22 September 2017

\section{DESCRIPTION}

A 62-year-old Indian male presented with complaints of minimally blurred vision in both eyes since 3-4 months. He was a known case of essential hypertension. On ocular examination, best corrected visual acuity was $20 / 40$ in both eyes with a +4D spherical correction. Anterior segment evaluation revealed immature senile cataract with normal intraocular pressures. On fundus examination, a discrete yellow dot was noted at the fovea of both eyes (right $>$ left), along with features of early hypertensive retinopathy (figure 1). He was diagnosed to have outer lamellar macular hole in both eyes. Spectral-domain optical coherence tomography (OCT) revealed hyporeflective space in outer retina at the foveal centre of both eyes (right $>$ left) (figure 2). A diagnosis of solar retinopathy was considered and on leading questions, he gave a history of performing religious rituals involving direct gazing into the rising sun soon after dawn for 5-10 min daily. He had been doing this for the past 30-35 years.

Solar retinopathy is a photic retinopathy occurring after direct exposure to sunlight. It is typically associated with viewing of the solar eclipse and religious sun gazing, and is also described following sunbathing, telescopic solar viewing, psychiatric disorders and psychotropic drugs. ${ }^{1}$ Presentation occurs within a few hours of exposure with impairment of the central visual function. Quantitative visual acuity can be variable depending on the severity of damage. OCT features of the outer retina, as seen in our patient, are very crucial for the diagnostic suspicion as clinical findings are generally subtle and may be easily missed. ${ }^{2}$

The visual prognosis of solar retinopathy is usually favourable, probably due to the resistance of

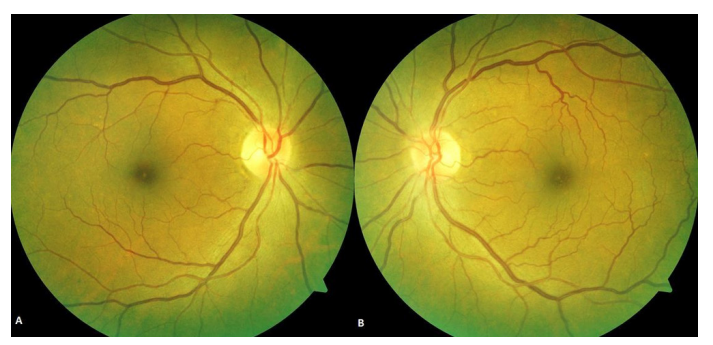

To cite: Sheemar A, Takkar $B$ Temkar S, et al. BMJ Case Rep Published Online First: [please include Day Month Year]. doi:10.1136/bcr-2017222690

Figure 1 Fundus photograph of the (A) right and (B) left eyes showing a yellow dot at the foveal centre. There are other features of early hypertensive retinopathy

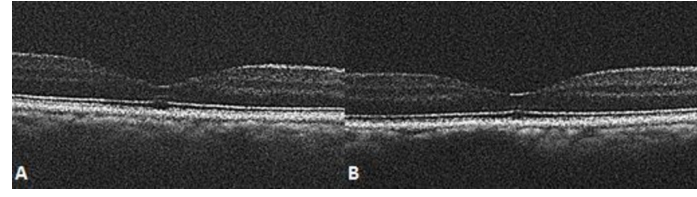

Figure 2 Spectral-domain optical coherence tomography vertical line scans of the macula of the $(A)$ right and (B) left eyes showing hyporeflective space in the outer retina at the foveal centre. There is disruption of the interdigitation and the ellipsoid zones, while the rest of the internal retinal architecture is maintained.

\section{Learning points}

- Optical coherence tomography features are very useful in diagnosis of solar retinopathy as clinical features are usually of subtle nature. Typical outer retinal changes should arouse suspicion and indicate leading questions for history of exposure to sunlight.

- The condition is easily preventable and awareness should be created specifically in areas where such religious rituals are common.

foveal cones to photochemical damage, and in most cases the visual loss is at least partly reversible. ${ }^{3}$ As it is an easily avoidable condition, prevention is of utmost importance. Therefore, awareness and sensitisation of people to this condition is required. Since the pathogenesis involves chemical reactions, the direct, prolonged and chronic exposure to sunlight made our patient vulnerable to the disease.

Contributors AS, BT and ST performed imaging and workup of the patient. AS and BT wrote the manuscript, PV critically revised it. PV holds the overall responsibility of the paper.

Competing interests None declared.

Patient consent Obtained.

Provenance and peer review Not commissioned; externally peer reviewed.

(c) BMJ Publishing Group Ltd (unless otherwise stated in the text of the article) 2017. All rights reserved. No commercial use is permitted unless otherwise expressly granted.

\section{REFERENCES}

1 Yannuzzi LA, Fisher YL, Krueger A, et al. Solar retinopathy: a photobiological and geophysical analysis. Trans Am Ophthalmol Soc 1987;85:120-58. and the left eye has minimal tortuosity of retinal vessels.
2 Kaushik S, Gupta V, Gupta A. Optical coherence tomography findings in solar retinopathy. Ophthalmic Surg Lasers Imaging 2004;35:52-5.

3 Mainster MA, Turner PL. Photic retinal injuries: mechanisms, hazards, and prevention. In: Ryan SJ, Ryan SJ, Retina. 5th ed. china: Elsevier:1555-63. Chapter 90. 
Copyright 2017 BMJ Publishing Group. All rights reserved. For permission to reuse any of this content visit http://group.bmj.com/group/rights-licensing/permissions.

BMJ Case Report Fellows may re-use this article for personal use and teaching without any further permission.

Become a Fellow of BMJ Case Reports today and you can:

- Submit as many cases as you like

- Enjoy fast sympathetic peer review and rapid publication of accepted articles

Access all the published articles

- Re-use any of the published material for personal use and teaching without further permission

For information on Institutional Fellowships contact consortiasales@bmjgroup.com

Visit casereports.bmj.com for more articles like this and to become a Fellow 